\title{
Conversion of the energy of the food into edible energy by two types of table poultry
}

\author{
By J. DAVIDSON AND J. MATHIESON \\ Rowett Research Institute, Bucksburn, Aberdeen \\ (Received I3 November 1964-Accepted 22 March 1965)
}

We have studied recently factors affecting the utilization of dietary metabolizable energy (ME) by table poultry (Davidson, McDonald, Mathieson \& Williams, I96I ; Davidson, Mathieson, Williams \& Boyne, 1964). The criterion of utilization has been the total amount of tissue energy laid down by the bird over the experimental period. This gives an indication of the value of the diet for the bird but does not indicate the efficiency of conversion of the diet, or of the metabolizable energy in the diet, into food for human consumption.

Because there was little information on this subject in the literature, especially for fast-growing strains developed recently in the United Kingdom, it was considered desirable to determine both total and edible energy in $3^{-3} \frac{1}{2} \mathrm{lb}$ birds of the Rhode Island Red $\times$ Light Sussex cross $(\mathrm{RIR} \times \mathrm{LS})$ frequently used experimentally at this Institute, and also of a modern commercial fast-growing hybrid strain (Chunky Chicks Ltd, Newbridge, Midlothian) extracted from a number of breeds including New Hampshire, Rhode Island Red and Cornish. This was done in two experiments in which, incidentally, we were studying the effects of adding to the diet small amounts of those amino acids calculated to be most limiting for growth.

\section{EXPERIMENTAL}

The experiments were designed to examine breed differences in total and edible energy, certain treatment effects mentioned below, and the breed $\times$ treatment interaction.

\section{Diets}

The starting diets, which were similar to diet $\mathbf{H}$ described in a previous paper (Davidson et al. I96I), contained $17 \%$ coarsely ground wheat, $45 \%$ ground barley, I $8 \%$ Sussex-ground oats, Io $\%$ white-fish meal, $3 \%$ maize gluten meal, $2 \%$ grass meal, $2 \%$ dried yeast, $0.5 \%$ bone flour, $1 \%$ limestone flour, $0.5 \%$ common salt containing $2 \frac{1}{2} \% \mathrm{MnSO}_{4} \cdot 4 \mathrm{H}_{2} \mathrm{O}, 0.15 \%$ of an antibiotic mixture $(3.6 \mathrm{~g}$ chlortetracycline hydrochloride/lb; Cyanamid of Great Britain Ltd, London), $0.05 \%$ coccidiostat (22.5\% nicarbazin; May \& Baker Ltd, Dagenham) and $0.5 \%$ vitamin mixture (containing vitamin $\mathrm{A}$ rooo i.u./g, vitamin $\mathrm{D}_{3} 200$ i.u./g and riboflavine $500 \mu \mathrm{g} / \mathrm{g}$; Isaac Spencer \& Co. Ltd, Aberdeen). For reasons unconnected with this study certain of the diets contained small additions of L-lysine, DL-methionine, L-arginine or a mixture of folic acid and cyanocobalamin. The results of this part of the work are being 
reported elsewhere (Davidson \& Mathieson, 1965 ). The diets contained $16 \frac{1}{2} \%$ crude protein and a concentration of metabolizable energy calculated after analysis and prediction by the method of Carpenter \& Clegg (1956) to be $2 \cdot 7 \mathrm{Mcal} / \mathrm{kg}$.

In each of the two experiments the starting diets were given until the chicks were 5 or 6 weeks old. After this, only one diet was offered because it was considered that any effects of supplementation would be evident by that time and would be reflected in subsequent growth even if supplements were discontinued. These finishing diets differed from the control starting diets in that $3 \%$ barley was substituted for $3 \%$ white-fish meal. They thus contained about $2 \%$ less crude protein than the starting diets. The food eaten by each group was recorded weekly.

\section{Procedure}

In both experiments 200 day-old cockerels of the RIR $\times$ LS cross and of the hybrid strain were given the control starting diet for 3 or 4 days and then weighed. Exceptionally light or heavy birds were discarded and ninety-six were randomized to eight groups of twelve birds. These groups were randomized to pens and to the experimental starting diets. The sixteen groups (eight of each strain) were housed in separate pens within the same hut, which was provided with background heating, and there were infrared lamps in each pen to give the increased temperatures needed in early life. The floor was covered with wood shavings which were changed every week. Artificial lighting was provided for $\mathrm{I} 3 \mathrm{~h}$ each day.

The birds were fed to appetite on the starting diets up to 6 weeks of age in Expt 1 and 5 weeks of age in Expt 2. The finishing diets were then offered until the end of the experiment when a mean live weight of about $3 \frac{1}{2} \mathrm{lb}$ had been reached. This was at 9 or 10 weeks of age for the hybrids and 12 weeks for the RIR $\times$ LS. Each group of twelve birds was then arranged in weight order and six were taken for determination of edible energy by choosing one at random from each pair in ascending weight order. The birds so chosen were killed, plucked and eviscerated, the legs being removed at the hock joint. The trussed birds along with the gizzard, heart, liver and neck were weighed, wrapped in aluminium foil and cooked in an autoclave for 20 min at $15 \mathrm{lb}$ pressure of steam. The gizzard, heart, liver and neck were cooked inside the bird in Expt I and separately in Expt 2. While still warm, the cooked tissues were separated into flesh, skin and giblets, the last-named comprising gizzard, heart and liver but not the neck, which was considered to have little value as a source of edible energy. Each of the three piles of cooked edible material from each group was weighed. Residual material, mainly bones, fat, and juice lost in cooking, was discarded. The flesh from each group and the skin and giblets (gizzard, heart and liver only) from four groups of the same strain of bird were minced and freeze-dried before analysis for crude fat (ether extract), crude protein $(\mathrm{N} \times 6 \cdot 25)$, ash and gross energy contents.

The birds from each group not chosen for cooking and separation of edible matter were analysed for total body energy as previously described (Davidson et al. 196r) to give a mean value per bird for the group. 


\section{Analytical methods}

Preparation of samples. The edible matter was minced in a household meat mincer and the weighed mince dried in a freeze-drier to a sponge-like cake containing about $2 \%$ moisture. This dried matter was weighed, sampled for determination of moisture and then minced again. The resultant material was stored in screw-capped bottles fitted with wax liners until required for analysis.

Crude fat. Fat was determined by a 'warm extraction' procedure, the flow of condensed diethyl ether passing through a Soxhlet thimble suspended in the vapour above the boiling diethyl ether.

Crude protein. Protein was measured, after determining nitrogen content, by the following modification of the Kjeldahl procedure described by the Association of Official Agricultural Chemists (1960).

To $\mathrm{I} g$ freeze-dried mince in a $500 \mathrm{ml} \mathrm{Kjeldahl} \mathrm{flask} \mathrm{were} \mathrm{added} 35 \mathrm{ml}$ water, $35 \mathrm{ml}$ conc. $\mathrm{H}_{2} \mathrm{SO}_{4}$ (sp. gr. I.84) and three 'Kjeltabs M' ('Thomson \& Capper Ltd, Liverpool) each containing $0.25 \mathrm{~g} \mathrm{HgO}$ and $5.00 \mathrm{~g} \mathrm{~K}_{2} \mathrm{SO}_{4}$. The flask plus contents was left at room temperature for at least $2 \mathrm{~h}$ and usually overnight to reduce frothing during subsequent digestion. The cooled digest was diluted with about $200 \mathrm{ml}$ water before adding $120 \mathrm{ml} 40 \%(\mathrm{w} / \mathrm{v}) \mathrm{NaOH}$ containing $5 \%(\mathrm{w} / \mathrm{v}) \mathrm{Na}_{2} \mathrm{~S}_{2} \mathrm{O}_{3} \cdot{ }_{5} \mathrm{H}_{2} \mathrm{O}$ and distilling into $10 \mathrm{ml} \mathrm{N}-\mathrm{H}_{2} \mathrm{SO}_{4}$. Back titration was carried out with $0.5 \mathrm{~N}-\mathrm{NaOH}$.

Gross energy. This was determined in an Adiabatic Bomb Calorimeter (A. Gallenkamp \& Co. Ltd, London).

Metabolizable energy. The concentration in the diets was calculated by the method of Carpenter \& Clegg (1956) after analysis for crude protein and crude fat by the methods of the Association of Official Agricultural Chemists (1960) and for starch and sugars by that of Clegg (1956). In our experience such calculated values usually lie within $2 \%$ of values obtained by biological trial (Davidson et al. I96r).

\section{RESULTS AND DISCUSSION}

The results were examined by the analysis of variance technique. There were no significant breed $\times$ treatment interactions and the significance of breed differences was determined from the breed component in the analysis of variance. The results by breed for each experiment are given in Table I along with the significance of differences. Each figure refers to forty-eight birds, six from each of eight groups. There was no significant difference between breeds in the dressed weights as a percentage of the live weights. Although in Expt I the weights of cooked edible material as a percentage of the live and dressed weights were significantly greater for RIR $\times$ LS than for the hybrids, it was not so in Expt 2. In both breeds the total weight of edible material after cooking was $30-33 \%$ of the live weight, divided into $20-23 \%$ from flesh, $6-7 \%$ from skin and $3-4 \%$ from giblets. The losses of $67-70 \%$ arose from discarding feathers, feet, head and intestines while dressing the birds before cooking (about $35 \%$ ), vapour and liquid losses during cooking (up to $15 \%$ ) and inedible cooked material which was mainly bones (about $20 \%$ ). On a basis of dressed or 'ready-to-cook" 
weight, the cooked edible material was around $50 \%$ of the dressed carcass weight, a figure in agreement with American figures published by Winter \& Clements (1957). Table $\mathrm{I}$ also shows that of the total body energy in the birds some $36-38 \%$ was in the edible material after cooking. The distribution was $19-22 \%$ in the flesh, $12-15 \%$ in the skin and about $3 \%$ in the giblets.

Table 1. Distribution of edible tissues and energy in Rhode Island Red $\times$ Light Sussex and in hybrid cockerels

(Mean values for forty-eight birds)

\begin{tabular}{|c|c|c|c|c|}
\hline \multicolumn{4}{|c|}{ (Mean values for forty-eight birds) } & \multirow{2}{*}{$\begin{array}{l}\text { Significance } \\
\text { of differenc }\end{array}$} \\
\hline Measurement & Expt no. & $\mathbf{R I R} \times \mathbf{L S}$ & Hybrid & \\
\hline Live weight (kg) & $\begin{array}{l}\mathbf{1} \\
2\end{array}$ & $\begin{array}{l}\mathrm{I} \cdot 54 \\
\mathrm{I} \cdot 68\end{array}$ & $\begin{array}{l}I \cdot 54 \\
I \cdot 69\end{array}$ & $\begin{array}{l}\text { NS } \\
\text { NS }\end{array}$ \\
\hline Dressed weight as $\%$ of live weight & $\begin{array}{l}\mathbf{I} \\
2\end{array}$ & $\begin{array}{l}65 \cdot 4 \\
65 \cdot 1\end{array}$ & $\begin{array}{l}64 \cdot 7 \\
65 \cdot 6\end{array}$ & $\begin{array}{l}\text { NS } \\
\text { NS }\end{array}$ \\
\hline Cooked flesh as $\%$ of live weight & $\begin{array}{l}I \\
2\end{array}$ & $\begin{array}{l}22 \cdot 5 \\
22 \cdot 1\end{array}$ & $\begin{array}{l}20 \cdot 1 \\
22 \cdot 8\end{array}$ & $\begin{array}{l}* * * \\
\text { NS }\end{array}$ \\
\hline Cooked skin as $\%$ of live weight & $\begin{array}{l}\text { I } \\
2\end{array}$ & $\begin{array}{l}6 \cdot 6 \\
6 \cdot 2\end{array}$ & $\begin{array}{l}6 \cdot 4 \\
7 \cdot 0\end{array}$ & $\begin{array}{l}\text { NS } \\
* *\end{array}$ \\
\hline Cooked giblets as $\%$ of live weight & $\begin{array}{l}\mathbf{I} \\
\mathbf{2}\end{array}$ & $\begin{array}{l}3 \cdot 7 \\
3 \cdot 3\end{array}$ & $\begin{array}{l}3 \cdot 2 \\
2 \cdot 8\end{array}$ & $* *$ \\
\hline $\begin{array}{l}\text { Total edible material after cooking } \\
\text { as } \% \text { of live weight }\end{array}$ & $\begin{array}{l}\mathrm{I} \\
2\end{array}$ & $\begin{array}{l}32 \cdot 8 \\
31 \cdot 6\end{array}$ & $\begin{array}{l}29 \cdot 7 \\
32 \cdot 6\end{array}$ & $\begin{array}{l}* * * \\
\text { NS }\end{array}$ \\
\hline $\begin{array}{l}\text { Total edible material after cooking } \\
\text { as } \% \text { of dressed weight }\end{array}$ & $\begin{array}{l}\text { I } \\
2\end{array}$ & $\begin{array}{l}50 \cdot 2 \\
48 \cdot 5\end{array}$ & $\begin{array}{l}45 \cdot 9 \\
49 \cdot 6\end{array}$ & NS** \\
\hline Body energy (Mcal) & $\begin{array}{l}\mathbf{I} \\
\mathbf{2}\end{array}$ & $\begin{array}{l}3.12 \\
3.55\end{array}$ & $\begin{array}{l}3 \cdot 17 \\
3 \cdot 84\end{array}$ & $\begin{array}{l}\text { NS } \\
\text { NS }\end{array}$ \\
\hline $\begin{array}{l}\text { Energy in cooked flesh as } \% \text { of } \\
\text { body energy }\end{array}$ & $\begin{array}{l}\mathbf{I} \\
\mathbf{2}\end{array}$ & $\begin{array}{l}20 \cdot 6 \\
21 \cdot 7\end{array}$ & $\begin{array}{l}19.3 \\
20.6\end{array}$ & $\underset{*}{\mathrm{NS}}$ \\
\hline $\begin{array}{l}\text { Energy in cooked skin as } \% \text { of } \\
\text { body energy }\end{array}$ & $\begin{array}{l}\mathbf{I} \\
2\end{array}$ & $\begin{array}{l}13 \cdot 0 \\
12 \cdot 4\end{array}$ & $\begin{array}{l}13 \cdot 3 \\
14 \cdot 9\end{array}$ & NS \\
\hline $\begin{array}{l}\text { Energy in cooked giblets as \% of } \\
\text { body energy }\end{array}$ & $\begin{array}{l}\mathbf{I} \\
2\end{array}$ & $\begin{array}{l}3 \cdot 4 \\
3 \cdot 3\end{array}$ & $\begin{array}{l}3 \cdot 1 \\
2 \cdot 7\end{array}$ & $\underset{* *}{\mathrm{NS}}$ \\
\hline $\begin{array}{l}\text { Total edible energy after cooking as } \\
\% \text { of body energy }\end{array}$ & $\begin{array}{l}\mathbf{1} \\
2\end{array}$ & $\begin{array}{l}36 \cdot 9 \\
37 \cdot 5\end{array}$ & $\begin{array}{l}35 \cdot 7 \\
38 \cdot 2\end{array}$ & $\begin{array}{l}\text { NS } \\
\text { NS }\end{array}$ \\
\hline Food eaten $(\mathrm{kg})$ & $\begin{array}{l}\text { I } \\
2\end{array}$ & $\begin{array}{r}5.4 \\
5.6\end{array}$ & $\begin{array}{l}4 \cdot 8 \\
4.7\end{array}$ & $\begin{array}{l}* * * * \\
* * * *\end{array}$ \\
\hline Metabolizable energy eaten (Mcal) & $\begin{array}{l}\mathbf{I} \\
2\end{array}$ & $\begin{array}{l}14.9 \\
15.4\end{array}$ & $\begin{array}{l}13.2 \\
13.0\end{array}$ & $\begin{array}{l}* * * * \\
* * *\end{array}$ \\
\hline $\begin{array}{l}\text { Total edible energy after cooking as } \\
\% \text { of metabolizable energy eaten } \\
\text { by the birds }\end{array}$ & $\begin{array}{l}I \\
2\end{array}$ & $\begin{array}{l}7.7 \\
8.6\end{array}$ & $\begin{array}{r}8.6 \\
\text { I1 } 3\end{array}$ & $\begin{array}{l}* * * \\
* * * *\end{array}$ \\
\hline
\end{tabular}

Because the hybrid birds reached $3 \frac{1}{2} \mathrm{lb}$ live weight several weeks earlier than the RIR $\times$ LS birds, and therefore had a shorter period of maintenance, it is not surprising that their overall efficiency in converting dietary ME into both body energy (Davidson $\&$ Mathieson, 1965) and cooked edible energy (Table I) was greater in each experiment than that of the RIR $\times$ LS birds. The considerably greater efficiency of the hybrids in Expt 2 was perhaps connected with the times of year at which these experi- 
Vol. 19

Food conversion into edible energy by poultry

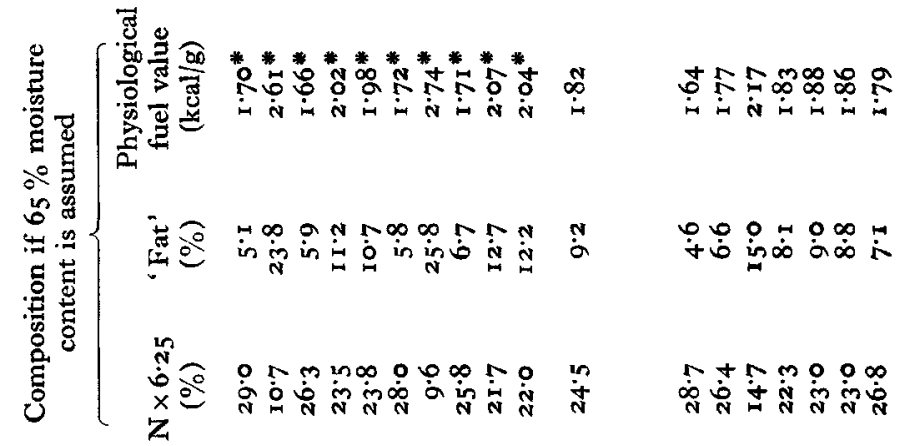

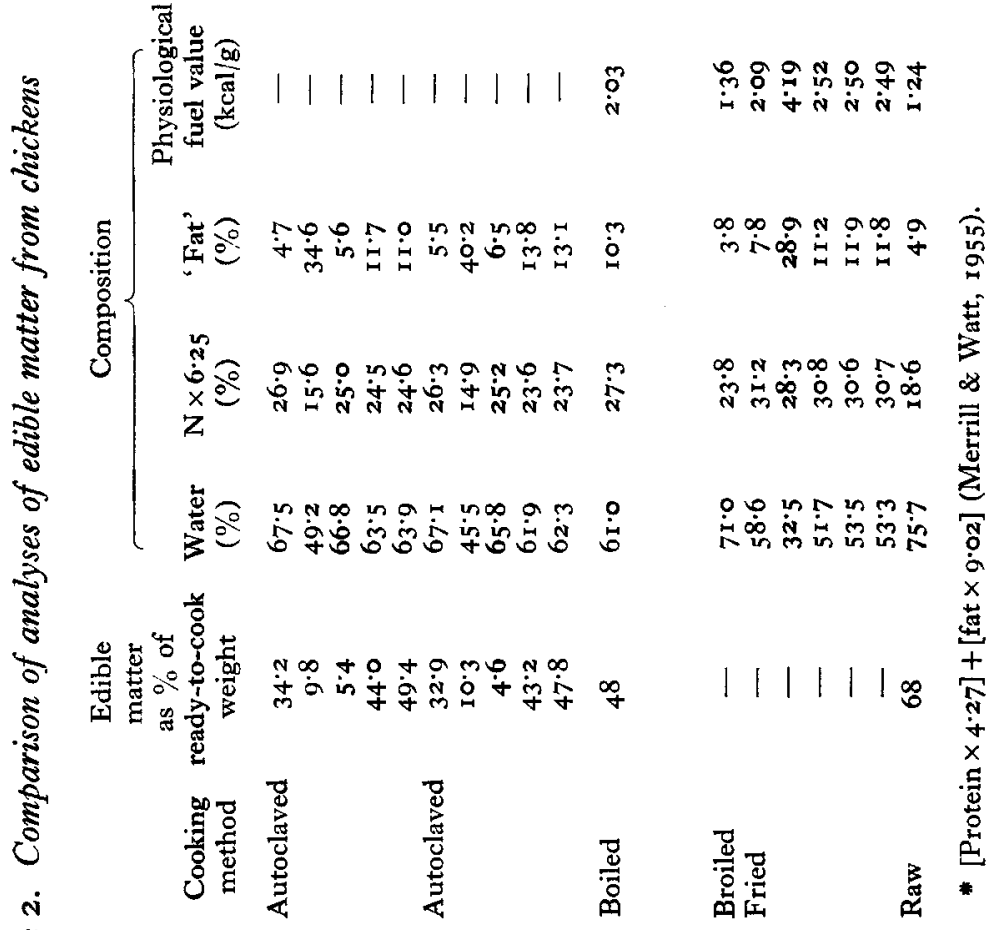

$\frac{0}{6}$

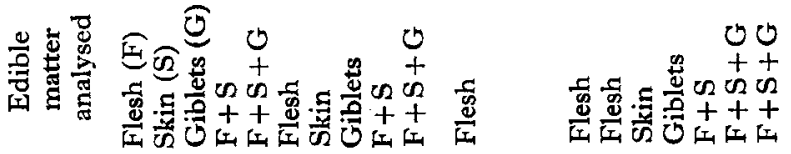

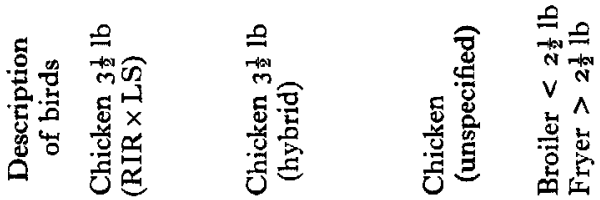

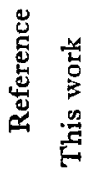

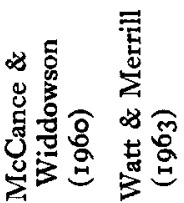


ments were carried out, Expt I being conducted during November to January and Expt 2 during May to August. It may be that the hybrid strain is more susceptible and the RIR $\times$ LS cross less susceptible to environmental temperatures or to factors associated with changes in day length.

Though some American studies (Hathaway, Champagne, Watts \& Upp, I953; Stotts \& Darrow, 1953) have shown breed differences in the yield of raw edible meat per unit of eviscerated or ready-to-cook weight, other studies (Morrison, Sauter, McLaren \& Stadelman, 1954; Kondra, Richards \& Hodgson, 1962) have not. In the work now presented a systematic difference in the amounts of cooked edible material obtained from fast- and slower-growing breeds was not found. In Canada, Orr (I955) has shown differences between strains when the basis of comparison was the live or plucked weight but not when it was the ready-to-cook weight. The general impression is thus gained that the improved growth rates at present obtained in raising chickens for the table do not appear to alter the proportion of edible material in the birds at around $3 \frac{1}{2} \mathrm{lb}$ live weight.

The analytical results of our study have been compared with values taken from standard works on the composition of foods for human consumption. Table 2 shows these values before and after adjustment to a constant moisture content of $65 \%$. The fatty-matter content of the flesh of our cockerels and even that of flesh after frying (Watt \& Merrill, 1963) was less than quoted in the tables of McCance \& Widdowson (1960) for the cooked flesh of chickens, a fact perhaps explained by different stages of development at killing. However, it is possible that part of the difference in fat content may have arisen from a difference in the methods used to measure fat, for the figure of McCance \& Widdowson was based on measurement made after saponification whereas our measurement and that of Watt \& Merrill (1963) were based on direct extraction with diethyl ether. However, it seems unlikely that the whole difference would be accounted for by the method of determination alone. The amount of cooked edible flesh derived from the dressed carcass (McCance \& Widdowson, 1960) was considerably greater than that from our own chickens, a finding which may also be explained by the stage of development of the bird when killed. From an examination of the data for individual components of the edible matter it would appear that procedures for cooking in the work reported from the United States leave less fat in the region of the skin than did our own procedure, or else the birds used by us contained more skin fat than the American birds. Whatever the reason, the 'skin' separated in our work contained more fat and consequently less protein than that separated in the American studies in which cooking was by frying and not steaming under pressure.

\section{SUMMARY}

I. In two experiments with both Rhode Island Red $\times$ Light Sussex and modern hybrid cockerels, groups of twelve were given various diets until they reached a mean live weight of about $3 \frac{1}{2} \mathrm{lb}$, when they were killed. This was at 12 weeks for the RIR $\times$ LS birds and at 9 or ro weeks for the hybrids.

2. Half the birds in each group were dressed and then cooked in an autoclave for 
$20 \mathrm{~min}$ at $\mathrm{I}_{5} \mathrm{lb}$ pressure of steam before separation of the edible material as flesh, skin and giblets, and subsequent analysis. The other half were analysed after removal of the contents of the alimentary tract to give an estimate of total body energy in each group.

3. There was no significant difference between the two breeds in the dressed and ready-to-cook weights as a percentage of live weights. Although in the first experiment the weights of cooked edible matter as a percentage of the live or dressed weights was greater for the slower-growing RIR $\times$ LS cross than for the hybrid birds, it was not so in the second experiment.

4. The total weight of edible material after cooking was $30-33 \%$ of the live weight, divided into $20-23 \%$ from the flesh, $6-7 \%$ from the skin and $3-4 \%$ from giblets. Of the total body energy in the birds, some $36-38 \%$ was in the edible material after cooking, with $19-22 \%$ in the flesh, $12-15 \%$ in the skin and about $3 \%$ in the giblets.

5. The overall efficiency in converting dietary metabolizable energy into edible energy was 7.7 and $8.6 \%$ for the Rhode Island Red $\times$ Light Sussex and 8.6 and $11.3 \%$ for the hybrid birds. The greater efficiency of the hybrid birds in converting dietary metabolizable energy into edible energy arises from their faster growth to the finishing weight and consequent reduction in the energy required for maintenance to that weight.

We are grateful to $\mathrm{Mr}$ A. W. Boyne for the statistical analysis, to Mrs Joyce E. Forsyth and Mr H. Bannerman for technical assistance and to the Misses M. Findlay and M. Henderson for looking after the birds.

\section{REFERENCES}

Association of Official Agricultural Chemists (I960). Methods of Analysis, 9th ed. Washington: Association of Official Agricultural Chemists.

Carpenter, K. J. \& Clegg, K. M. (1956). 7. Sci. Fd Agric. 7, 45.

Clegg, K. M. (1956). F. Sci. Fd Agric. 7, 40.

Davidson, J., McDonald, I., Mathieson, J. \& Williams, R. B. (196r). F. Sci. Fd Agric. 12, 425.

Davidson, J. \& Mathieson, J. (1965). Brit. Poult. Sci. 6, 225.

Davidson, J., Mathieson, J., Williams, R. B. \& Boyne, A. W. (1964). F. Sci. Fd Agric. I5, 316.

Hathaway, H. E., Champagne, G. B., Watts, A. B. \& Upp, C. W. (1953). Poult. Sci. 32, 968.

Kondra, P. A., Richards, J. F. \& Hodgson, G. C. (1962). Poult. Sci. 41, 922.

McCance, R. A. \& Widdowson, E. M. (1960). Spec. Rep. Ser. med. Res. Coun., Lond., no. 297, 3rd ed.

Merrill, A. L. \& Watt, B. K. (1955). U.S. Dep. Agric. agric. Handb. no. 74.

Morrison, M. A., Sauter, E. A., McLaren, B. A. \& Stadelman, W. J. (I954). Poult. Sci. 33, I 122.

Orr, H. L. (1955). Poult. Sci. 34, 1093.

Stotts, C. E. \& Darrow, M. I. (1953). Poult. Sci. 32, 145.

Watt, B. K. \& Merrill, A. L. (1963). U.S. Dep. Agric. agric. Handb. no. 8.

Winter, A. R. \& Clements, P. (1957). F. Amer, diet. Ass. 33, 800. 